\title{
Gender Differences in Knowledge, Use, and Collection of Wild Edible Plants in Three Spanish Areas
}

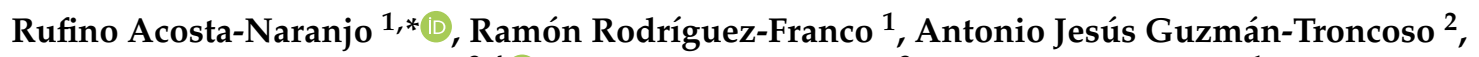 \\ Manuel Pardo-de-Santayana ${ }^{3,4} \mathbb{D}^{\mathbb{D}}$, Laura Aceituno-Mata ${ }^{3}$, José Gómez-Melara ${ }^{1}$, Pablo Domínguez ${ }^{5,6}{ }^{(\mathbb{B} \text {, }}$ \\ Isabel Díaz-Reviriego ${ }^{7}$ (D) Jessica González-Nateras ${ }^{1}$ and Victoria Reyes-García ${ }^{6,8} \mathbb{D}$ \\ 1 Departamento de Antropología Social, Universidad de Sevilla, 41004 Sevilla, Spain; \\ ramon@cactuslab.es (R.R.-F.); jgmelara@us.es (J.G.-M.); yiskahcubensis@gmail.com (J.G.-N.) \\ 2 Universidad Nacional de Educación a Distancia (UNED), 28015 Madrid, Spain; procusto@riseup.net \\ 3 Departamento de Biología (Botánica), Universidad Autónoma de Madrid, 28049 Madrid, Spain; \\ manuel.pardo@uam.es (M.P.-d.-S.); aceitunomata@yahoo.es (L.A.-M.) \\ 4 Centro de Investigación en Biodiversidad y Cambio Global (CIBC-UAM), Universidad Autónoma de Madrid, \\ 28049 Madrid, Spain \\ 5 Laboratoire Geographie de 1 Environnement, CNRS-UT2J, 31058 Toulouse, France; \\ pablo.dominguez@univ-tlse2.fr \\ 6 Institut de Ciència i Tecnologia Ambientals (ICTA), Universitat Autònoma de Barcelona, Bellatera, \\ 08193 Barcelona, Spain; victoria.reyes@uab.cat \\ check for
updates \\ Citation: Acosta-Naranjo, R.; \\ Rodríguez-Franco, R; Guzmán-Troncoso, A.J.; \\ Pardo-de-Santayana, M.; Aceituno-Mata, L; \\ 7 Social-Ecological Systems Institute (SESI), Faculty of Sustainability, Leuphana Universität Lüneburg, \\ Universitaetsallee 1, 21335 Lüneburg, Germany; diaz@leuphana.de \\ 8 Institució Catalana de Recerca i Estudis Avançats (ICREA), 08010 Barcelona, Spain \\ * Correspondence: racosta@us.es
} Gómez-Melara, J.; Domínguez, P.; Díaz-Reviriego, I.; González-Nateras, J.; Reyes-García, V. Gender Differences in Knowledge, Use, and Collection of Wild Edible Plants in Three Spanish Areas. Sustainability 2021, 13, 2639. https://doi.org/10.3390/su13052639

\section{Academic Editors:}

\section{Francisco Entrena-Duran,}

Victor Muñoz-Sanchez and Antonio M. Perez-Flores

Received: 15 January 2021

Accepted: 20 February 2021

Published: 2 March 2021

Publisher's Note: MDPI stays neutral with regard to jurisdictional claims in published maps and institutional affiliations.

Copyright: (c) 2021 by the authors. Licensee MDPI, Basel, Switzerland. This article is an open access article distributed under the terms and conditions of the Creative Commons Attribution (CC BY) license (https:/ / creativecommons.org/licenses/by/ $4.0 /)$.

Abstract: Many ethnobotanical studies have shown differences in the knowledge and practices held by men and women. Using ethnographic fieldwork, a survey, and secondary data from three different areas in Spain, this study shows a geographical pattern in women's and men's relations with wild edible plants. In the case studies from Southern Spain, Doñana, and Sierra Morena Extremeña, women gather less wild edible plants than men, while in the Central Spain case study, Sierra Norte de Madrid, the difference is less marked. We explain this difference through the construction and distribution of agrarian spaces, particularly with regards to land tenure type and urban centers size. In the southern cases, large agrarian properties are more prevalent than in Sierra Norte de Madrid, where common lands and small and medium properties predominate. Additionally, in Doñana, big urban agro-towns dominate, whereas in Sierra Norte de Madrid and Sierra Morena Extremeña little towns are the norm. Overall, our study suggests that gendered differences in the use of natural resources are better understood if contextualized in a large socioecological context.

Keywords: biodiversity; ethnobotany; gender; local knowledge; Spain

\section{Introduction}

Despite the importance of inter-individual differences in ecosystem and biodiversity knowledge, use, and management [1-3], researchers do not always collect information on local knowledge systems in a way that recognizes intra-cultural differences in knowledge systems. Several researchers have criticized this perspective, arguing that the views of other social actors, particularly women, should also be considered in the quest to have a complete picture of local knowledge systems [2-6]. Recent research shows that informant's socioeconomic characteristics, and particularly the performance of activities such as agriculture, husbandry, silviculture, gathering, fishing, or hunting, shape the relation that they hold with the natural environment $[7,8]$.

Many studies have also recognized the need to develop a gender perspective when analyzing natural resource management [9-11]. Despite this rising interest, few ethnobotanical 
studies focus on understanding how gender shapes human relations with nature [2,6,12]. Such gender bias in ethnobotanical research conceals not only women's perspectives on the ecosystem, but also the differentiated perspective of men, who are usually enclosed in the hegemonic masculinity model $[9,13]$. Moreover, besides gender, other individual characteristics such as class, occupation, ethnicity, formal education, social status, or religion should also be considered for understanding the diverse ways in which women and men interact with the environment $[3,14,15]$. This is so because even though most practices and uses of spaces are gendered, the way in which women and men interact with the environment is closely related to the cultural and socioeconomic context in which their activities are embedded $[2,7,16,17]$. In this paper, we contribute to the gender perspective in ethnobotany by analyzing gender differences in the recognition, consumption, and gathering of wild edible plants (WEP). We particularly focus on the spatial dimension. Previous ethnobotanical work has noted how WEP location affects whether WEP gathering is done by women or men [18-21]. For example, sociocultural norms may constrain women's access to the forest or to other areas far from the domestic realm, implying that men would be in charge of activities in these areas, such as WEP collection [11,22]

In the same line, previous research in Spain has described gendered differences in the knowledge and management of cultivated and wild plants, particularly between meridional and northern areas [11]. Previous ethnographic and sociological studies have also documented differences in men's and women's involvement in agricultural activities in different areas of Spain. Thus, Porto and Vicente-Mazariegos [23] differentiate between areas with two types of land holdings, exclusive production units and familiar production and cohabitation units, the latter of which are characterized by the performance of agricultural tasks by all the family members who cohabit in a house near their agricultural fields. In familiar production and cohabitation units, the spatial continuity between the house (spaces with feminine prevalence) and the agricultural fields facilitates women's involvement in agricultural work.

Following this line of research, in this work we compare women's and men's WEP knowledge, gathering, and consumption across southern and central areas of Spain. Our working hypothesis is that contextual factors, namely land ownership and urbanization, are important in explaining gendered differences in the recognition, gathering, and consumption of WEP.

As in previous ethnobotanical works (e.g. [3]), we use the prevalent gender divide in the study areas that associate gender to the binary and heteronormative perception of gender roles and stereotypes that are assigned in base to a cultural perception of genitals and sex (i.e., man and woman). We recognize that gender dynamics and identities are much more complex, even if they are not tackled in this study.

\section{Research Areas}

This research was conducted within the framework of a study focusing on trends in the consumption and gathering of WEP in Spain (see [24]). We particularly focus on three case studies: Doñana, Sierra Morena Extremeña, and Sierra Norte de Madrid (Figure 1). We selected sites with nucleated settlement pattern (i.e., where habitat dispersion was low). Different members of the research team have worked long-term in the study areas, accumulating a good amount of socio-anthropological information, including information on gender relations [25-28]. This knowledge base has been used for the interpretation of quantitative results. 


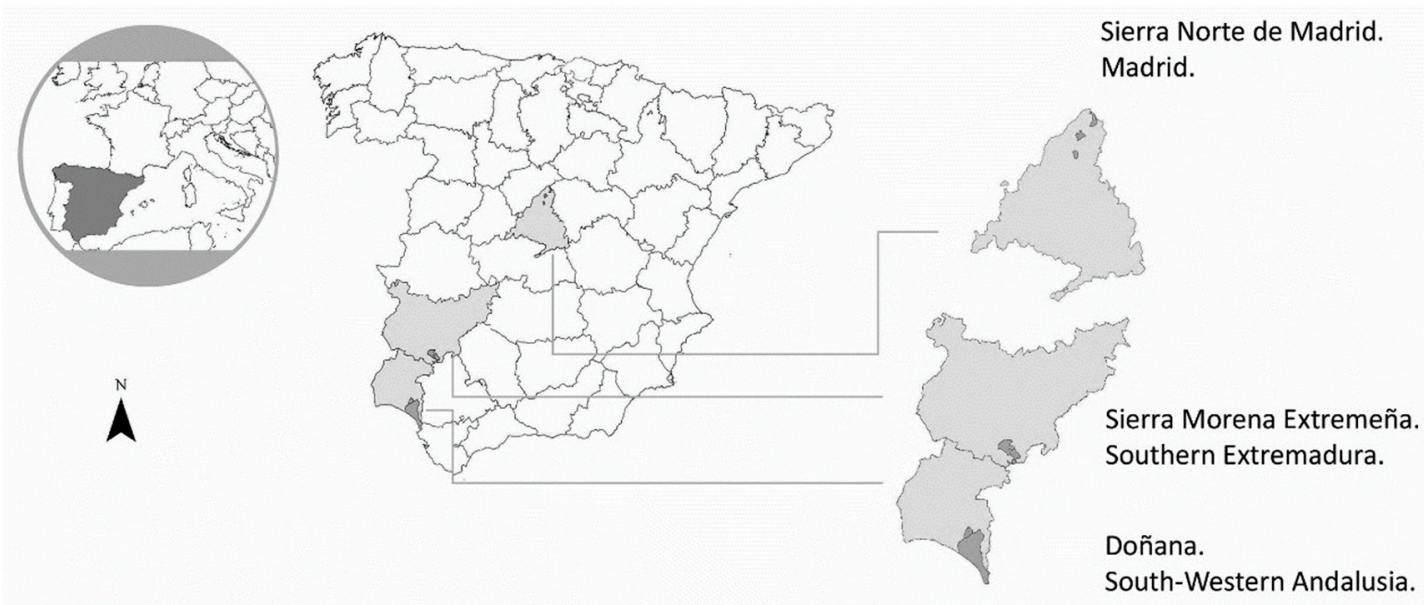

Figure 1. Research areas.

One of the study areas is a plain territory near the Atlantic Ocean (Doñana), and the other two are mountainous regions in inner Spain (Sierra Morena Extremeña and Sierra Norte de Madrid) (Figure 1). Exclusive production units predominate in Doñana and Sierra Morena Extremeña, whereas familiar production and cohabitation units predominate in Sierra Norte de Madrid. With this typology in mind, and based on our previous research in these areas, below we provide an ecological, economic, and social characterization of each area, attending to the gender roles in relation to farming.

\subsection{Doñana}

The study took place in the settlements of Almonte and Rociana del Condado (Huelva, Andalusia), located in the surrounding area of Doñana Natural and National Parks. The area has a Mediterranean climate with oceanic influences. The average annual temperature is $17^{\circ} \mathrm{C}$, and the average annual precipitation is $550-650 \mathrm{~mm}$. [29]. The topography of the area is flat. Traditionally, the meridional part of the study area has not been suitable for tilling and other productive activities due to its sandy areas and marshlands. Together with hunting and gathering, the main economic activity traditionally practiced in that area was slash-and-burn agriculture. The best agricultural conditions are located in the north, where vineyards and olive groves play a central role. Latifundismo (landlordism) is the predominant land tenure system. Agrarian properties bigger than 200 ha occupy up to $63.41 \%$ of the territory (Figure 2), with the largest properties along the extreme southern end, close to the National Park. Small and medium holdings are more common in the north, in particular around the vineyards [30].

Since the 1970s, new farming practices and recreational and touristic activities have changed the landscape of the area. Large holdings of intensive high-tech agrarian proprieties produce horticultural crops and fruits with seasonal migrant workforces [31]. At the same time, tourism has become an important economic activity on the coast and the Natural Park surroundings. There are also remarkable agribusiness and service sectors, especially in Almonte. The population has increased from 16,253 inhabitants in 1950 to 32,046 in 2019. Large urban centers concentrate most of the population of the area, 24,191 inhabitants in Almonte and 7855 in Rociana, and scattered populations have almost disappeared (Table 1) [32,33]. 


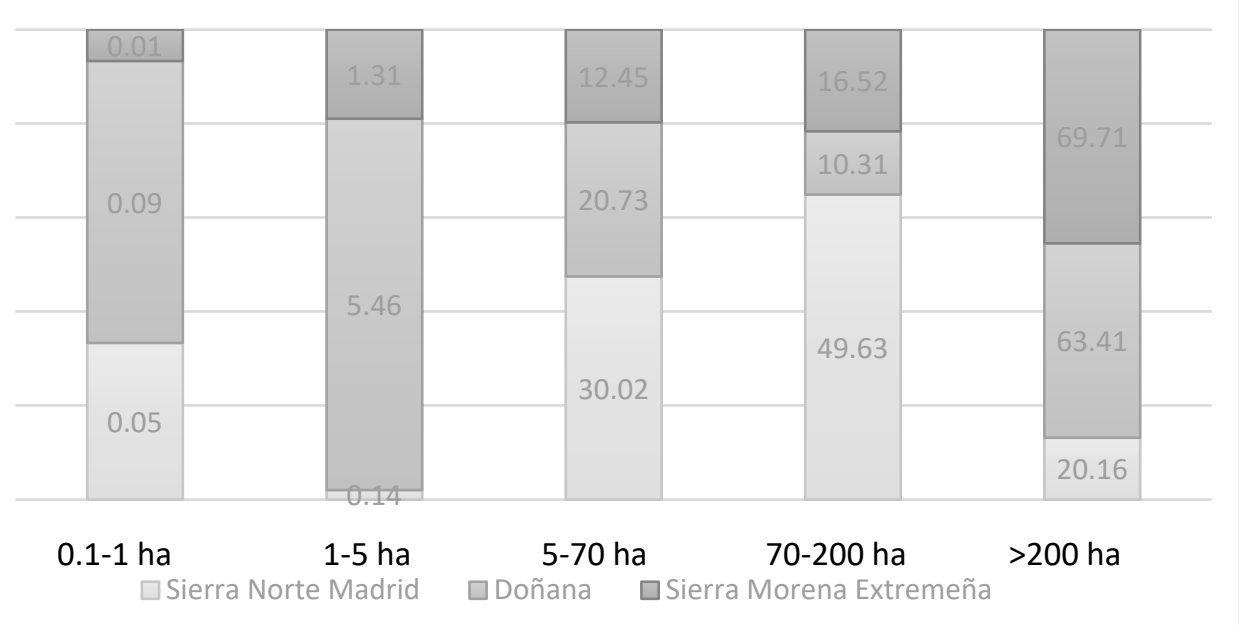

Figure 2. Land ownership structure distribution of each site in percentages.

Table 1. Inhabitants of Urban centres.

\begin{tabular}{cc}
\hline Urban Center & Population \\
\hline Sierra Norte de Madrid & \\
\hline Valdemanco & 914 \\
\hline Montejo & 353 \\
\hline Buitrago & 1884 \\
\hline Doñana & 24,191 \\
\hline Almonte & 7855 \\
\hline Rociana & \\
\hline Sierra Morena & 379 \\
\hline Pallares & 685 \\
\hline Puebla del Maestre & 153 \\
\hline Santa Maria de Navas
\end{tabular}

In Doñana, men's dominance in agricultural activities relates to land ownership and modes of production. There are almost no agrarian properties managed by women and the number of properties co-management by men and women is insignificant [34]. Until the 1960s, olive groves and vineyards had a high rate of feminine work, but women's activities were always subordinated to men. Women, hired or from the household, were constantly supervised and controlled by their relatives or by manijeros (foremen), and never allowed to work alone [35]. Moreover, women were typically remunerated less than men, their work being considered as a complement to the work of their male partners.

Nowadays, vineyards are disappearing, and olive groves employ a high percentage of male immigrant workforces. When women are employed, the same conditions remain: they rarely work alone, oftentimes following the instructions of a male family member, and their performance is always under suspicion [36]. Conversely, the consolidated intensive monoculture agrobusiness in Doñana is employing a high number of female immigrant workers to gather red fruits. Local women are also seasonally employed in this industry, handling the final product in factories [37]. Overall, local women's involvement in agricultural activities in Doñana is disappearing, with only some women occasionally hired in monoculture harvesting, resulting in an increasing masculinization of farming. Feminine work has moved towards urban areas, into the tertiary sector and particularly into the increasingly important tourism sector. 


\subsection{Sierra Morena Extremeña}

Our second case study took place in the villages of Pallares, Santa María de Navas, and Puebla del Maestre (Badajoz, Extremadura). The area is settled in a medium mountain Mediterranean territory, with a highest altitude of 700 m.a.s.l. The weather in the area is continental Mediterranean, with an average rainfall ranging from 600 to $800 \mathrm{~mm} /$ year and an annual average temperature of $14.7^{\circ} \mathrm{C}$ [38]. The prevailing agroecosystem is the dehesa, an area of open woodlands resulting from the transformation of the original Mediterranean forest with a dominance of holm oak (Quercus ilex subsp. ballota (Desf.) Samp.) into multifunction farming systems used for grazing, silviculture, and rotation cereal cropping across large private farms. The value of these open woodlands for biodiversity conservation has been repeatedly noted and largely lies in their ability to maintain a higher diversity of plants and animals than other habitats in the same environment [39,40]. Large estates ( $>200$ ha) occupy $69.72 \%$ of the territory and are the most common type of land ownership in the area (Figure 2). In Puebla del Maestre, a group of small landowners base their economy in olive groves, but this agroecosystem occupies a small surface of the studied area [25]. The population has decreased from 5023 inhabitants in 1950 to 1217 in $2019[32,33]$. In the past, there were some scattered settlements within the large estates, but this settlement pattern has disappeared, and the population is now concentrated in urban areas. Urban areas, however, are small: 685 inhabitants in Puebla del Maestre, 379 in Pallares, and 153 in Santa María (Table 1).

The Sierra Morena is a deprived area of Spain, with a high rate of unemployment; ageing and depopulation are also critical problems in the area [29,41]. In this zone, agrarian properties are in crisis. Most dehesas have specialized in husbandry, crops have disappeared, and olive groves have been semi-abandoned. Consequently, agricultural labor has been drastically reduced [42]. While the agricultural activity is in crisis, there is a small amount of economic activity linked to the service sector and a seasonal migration linked to hotel businesses in Ibiza.

Until the 1960s, the collection of acorns, olives, and carobs was largely a feminine work [25]. As in Doñana, female agricultural work was supervised and controlled by men. Nowadays feminine work has virtually disappeared both in the dehesa and in the olive groves. In some cases, the management of the dehesa is performed by a single person, namely a man who moves every day from his home in the urban center to the dehesa. Home gardens are managed only by men and mostly as a leisure activity [26].

\subsection{Sierra Norte de Madrid}

The third case study was conducted in the localities of Buitrago, Montejo, and Valdemanco, in a mountain area north of Madrid (Figure 1). This region includes a granitic mountain range rising up to 2000 m.a.s.l. The climate in the area is continental Mediterranean, the average temperature is $10.6^{\circ} \mathrm{C}$, and annual rainfall ranges from 600 to $1000 \mathrm{~mm}$. In the lowest area, we find holm oak forests and aromatic scrub flora. In the mountain side, until $1600 \mathrm{~m}$ height, the forests are mainly composed of Pyrenean oak (Quercus pyrenaica Willd.), patched with pastures and scrubland populations dominated by rock rose (Cistus ladanifer L. and Cistus laurifolius L.). The highlands are mainly pastures and leguminous scrub formations. Compared with Doñana and Sierra Morena, Sierra Norte has the lowest rate of land concentration, since agrarian properties bigger than 200 ha occupy just $20.16 \%$ of the territory. Estates between 70 and 200 ha are the most common (49.63\%) (Figure 2). Moreover, a significant portion of the large agrarian properties are communal lands, which occupy $63.09 \%$ of Montejo, $16.32 \%$ of Valdemanco, and $39.55 \%$ of Buitrago [43].

As in the other two study areas, the settlement pattern in Sierra Norte de Madrid is nucleated. Moreover, the population of the three villages has experienced an increase in the last decades, from 1771 inhabitants in 1950 to 3151 in 2019 [32,33].

The current population is 914 inhabitants in Valdemanco, 353 in Montejo, and 1884 in Buitrago (Table 1). Indeed, population increase is explained by the proximity of the area 
to Madrid, Spain's capital city, which has boosted the construction and tertiary sectors, with the increase of tourism and secondary residences. Moreover, a significant number of residents in the study area commute daily to Madrid.

Until the mid-twentieth century, the local population maintained a subsistence economy based on cattle farming, forest resource extraction, and agriculture. As in Sierra Morena, the decline of traditional agriculture in the 1960s led to a migration flow to urban areas and the abandonment of agrarian activities $[28,44]$. Such populations maintain close bonds with their villages, returning on weekends and holidays.

In the past, women in Sierra Norte de Madrid participated in agricultural activities. Women worked in home gardens, pastured cattle on the highest communal lands, and participated in the harvest of products in family agricultural lands [28]. Nowadays, while men take care of the agrarian proprieties furthest from the urban centers, women continue to manage home gardens, sometimes with their male partners [11].

\section{Materials and Methods}

\subsection{Data Collection}

In order to understand gender dynamics in the use of WEP, we merged qualitative and quantitative data on their past and present use. We focused on qualitative data for understanding the context of WEP gathering and consumption, and on quantitative data for assessing the number of plants recognized, consumed, and gathered.

Data were collected in various stages. Ethnographic information comes from several decades of work in the study sites. Since 1988, two of the authors have conducted ethnoecological research in Doñana and Sierra Morena [25,27,42,45]. In addition, one of the authors was born in Pallares (Sierra Morena), where he returns frequently for personal and research purposes. Another author has dwelled and done ethnobotanical research in Sierra Norte de Madrid since 2007 [28,46]. Data on WEP gathering comes from semi-structured interviews and a survey. Between 2012 and 2013, we conducted semi-structured interviews with informants that had a good knowledge of the most salient WEPs in each territory.

\subsection{Interviews}

We selected people with good knowledge of plants and their uses in the three study areas, using a snowball technique. All of them were residents in the villages. Men had had experience with agrarian work and women with household work. We conducted semi-structured interviews with 18 men and 13 women, with a range of ages of 45-88 (mean 68.6), at Extremadura. In Doñana, all the informants selected were informants who had a reputation for their knowledge and use of wild edible plants in the area. These key informants were a total of 15 men and 4 women, with an average age of 60.7 years old, ranging from 50 to 75 years old. To contact them, we used the method of snowball sampling. In Sierra Norte de Madrid, we selected a sample of 132 informants that had lived in the area before 1960, using the method of snowball sampling. Informants had an average age of 68 years old, $50 \%$ of them being woman. To cover all the regional differences of Sierra Norte, fieldwork was carried out in 28 of the 42 villages of the area. All the infomants still lived in the region and had experienced the transformation of traditional agricultural society that occurred in the last century.

\subsection{Surveys}

In 2013, we surveyed a randomized sample of 150 persons in Doñana, 150 in Sierra Morena, and 180 in Sierra de Madrid. In Sierra Norte de Madrid, 52\% of the sample were women and $48 \%$ were men; in Doñana, $53 \%$ were women and $47 \%$ were men; and in Sierra Morena Extremeña, $48 \%$ were women and 52\% were men (Table 2). In all three cases, regarding age distribution we selected $33 \%$ of informants in the each of the three age categories selected $(<30 ; 31-60$; and $>60)$ (Table 3$)$ and analyzed their knowledge, gathering, and use of seven WEPs present in the area. 
Table 2. Sample distribution by gender.

\begin{tabular}{cccc}
\hline Study Area & N & Women & Men \\
\hline Doñana & 150 & $53 \%$ & $47 \%$ \\
Sierra Morena Extremeña & 150 & $48 \%$ & $52 \%$ \\
Sierra Norte de Madrid & 180 & $52 \%$ & $48 \%$ \\
\hline
\end{tabular}

Table 3. Sample distribution by age.

\begin{tabular}{ccccc}
\hline Study Area & $\mathbf{N}$ & $<\mathbf{3 0}$ & $\mathbf{3 1 - 6 0}$ & $>\mathbf{6 0}$ \\
\hline Doñana & 150 & $33 \%$ & $33 \%$ & $33 \%$ \\
Sierra Morena Extremeña & 150 & $33 \%$ & $33 \%$ & $33 \%$ \\
Sierra Norte de Madrid & 180 & $33 \%$ & $33 \%$ & $33 \%$ \\
\hline
\end{tabular}

Our survey included basic individual sociodemographic information (i.e., age, gender, type of residence, type of link with the territory, and occupation) and information on WEP knowledge and use. Specifically, we showed informants a visual stimulus (i.e., the fresh plant, a picture, or an herbarium voucher) of seven WEPs traditionally consumed in the area, where the plant part consumed could be easily recognized. We asked informants to identify each of the plants by providing the local name. Then, we asked informants to provide information on the use of the plants recognized and to report whether they had consumed and gathered them in the last year.

As there are important cultural and environmental differences between the three areas, we selected different WEPs to be included in the survey applied in each area. However, to ensure comparability, we used the same criteria to select WEP. Thus, to select the plants, we used information from semi-structured interviews to identify WEP locally considered relevant and mainly gathered for self-consumption or exchange. Then, from that list, we randomly selected WEP to include in the survey. At each site, we included at least one fruit, one vegetable, one beverage and one seasoning species. Table 4 shows a list of the WEP included in the survey of each area. Information on the most common ways of consumption (i.e., raw or cooked) comes from semi-structured interviews.

\subsection{Data Analysis}

To evaluate gender differences regarding WEP knowledge and use, data were grouped by study area. We used measures of central tendency to expose and analyze the data. Specifically, for each person, we counted the number of plants recognized, consumed, and gathered out of the seven plants included in the survey. We then aggregated the results by area and gender. To test whether differences in the number of plants recognized, consumed, and gathered by men and women were statistically significant, we used a $t$-test analysis. We consider a result as significant when $p \leq 0.05$.

In the second part of our analysis, we crossed our data on gendered WEP recognition, consumption, and gathering with information from land ownership structure and settlement patterns to explore whether gendered differences in WEP recognition, consumption, and gathering could be explained by these variables. Specifically, we used the systematization and synthesis of the knowledge obtained from the ethnography carried out over the years and secondary information of the study areas to provide qualitative explanations of gender differences based on the use of the space. We selected information from interviews and our field diaries related to gender differences on agricultural activities, space, and WEPs. 
Table 4. Ways of plant consumption in the three areas.

\begin{tabular}{|c|c|}
\hline Doñana & \\
\hline Asparagus acutifolius L. & Cooked \\
\hline Chamaerops humilis L. & Raw \\
\hline Glycycrrhiza glabra L. & Raw \\
\hline Mentha pulegium L. & Cooked \\
\hline Rubus ulmifolius Schott & Raw \\
\hline Scolymus hispanicus L. & Cooked \\
\hline Thymbra capitata (L.) Cav. & Cooked \\
\hline \multicolumn{2}{|l|}{ Sierra Morena Extremeña } \\
\hline Asparagus acutifolius L. & Cooked \\
\hline Foeniculum vulgare Mil. & Raw and Cooked \\
\hline Helichrysum stoechas (L.) Moench & Cooked \\
\hline Rubus ulmifolius Schott. & Raw \\
\hline Rumex pulcher L. & Cooked \\
\hline Scolymus hispanicus L. & Cooked \\
\hline Thymus mastichina (L.) & Cooked \\
\hline \multicolumn{2}{|l|}{ Sierra Norte de Madrid } \\
\hline $\begin{array}{l}\text { Armeria arenaria (Pers.) Schult. subsp. } \\
\text { segoviensis (Gand. ex Bernis) Nieto Fel. }\end{array}$ & Raw \\
\hline Crataegus monogyna Jacq. & Raw \\
\hline Prunus spinosa L. & Cooked \\
\hline Rubus ulmifolius Schott. & Raw \\
\hline Rumex papillaris Boiss. \& Reut. & Raw and Cooked \\
\hline Scolymus hispanicus L. & Cooked \\
\hline Thymus zygis Loefl. ex L. & Cooked \\
\hline
\end{tabular}

\section{Results and Discussion}

\subsection{Gender Differences in WEP Recognition, Consumption, and Gathering}

Survey results show a balanced distribution between the number of WEP that women and men are able to recognize in the three study areas (Table 5). Small differences can be observed, with men recognizing more plants than women, particularly in Doñana, with a gender differential of $5.31 \%$. Results from a $t$-test showed a difference at the limit of statistical significance $(p=0.05)$ only in the case of Doñana.

The results of the analysis of the variable consumption show noticeable differences in the average number of plants that women and men consume. As for recognition, the most remarkable difference is in the Doñana case study, where men consume an average of $11.6 \%$ more WEP than women, this difference being statistically significant $(p=0.01)$. Differences in average consumption of WEP by women and men in Sierra Morena Extremeña $(3.60 \%)$ and Sierra Norte de Madrid $(4.55 \%)$ were not statistically significant.

From the three variables analyzed, the most remarkable differences are in WEP gathering. The cases of Doñana and Sierra Morena Extremeña are noteworthy, with differences of $26.68 \%$ and $14.50 \%$, respectively. In both cases, men report gathering WEP more often than women. In Sierra Norte de Madrid, the differential is only 3.89\%, with men also reportedly gathering more WEP than women. The difference in Doñana and Sierra Morena Extremeña is highly statistically significant $(p<0.001)$. 
Table 5. Average of plants recognized, consumed, and gathered by site and gender.

\begin{tabular}{|c|c|c|c|c|c|c|c|c|c|c|c|c|c|c|c|c|c|c|}
\hline \multirow[b]{2}{*}{ Study Area } & \multicolumn{6}{|c|}{ Recognition } & \multicolumn{6}{|c|}{ Gathering } & \multicolumn{6}{|c|}{ Consumption } \\
\hline & $\mathbf{W}$ & SD & $\mathbf{M}$ & SD & $p$-Value & Dif & $\mathbf{W}$ & SD & $\mathbf{M}$ & SD & $p$-Value & Dif & W & SD & $\mathbf{M}$ & SD & $p$-Value & Dif \\
\hline Doñana & 6.05 & 1.54 & 6.42 & 1.21 & $0.05 *$ & -5.31 & 4.13 & 1.84 & 4.94 & 1.62 & $0.01 *$ & -11.67 & 1.82 & 1.80 & 3.69 & 2.11 & $0.01 *$ & -26.68 \\
\hline Sierra de Madrid & 5.29 & 1.54 & 5.14 & 1.67 & & 2.11 & 3.96 & 1.64 & 4.21 & 1.88 & & -3.60 & 3.05 & 2.04 & 3.33 & 2.28 & & -3.89 \\
\hline
\end{tabular}

$\mathrm{W}=$ women; $\mathrm{M}=$ men; $\mathrm{Dif}=\%$ Difference between $\mathrm{M}$ and $\mathrm{W} .{ }^{*}$ Significance $\leq 0.05$. 


\subsection{WEP Gathering, a Clearly Gendered Activity in Southern Spain}

We found no gendered differences in the recognition of WEPs, a finding that can be explained through generalized exposure to WEPs in the three areas. In other words, as people can interact with WEPs in different environments, including the countryside and villages, but also in houses, there is no reason to think WEP knowledge is different between genders. Because WEPs can be brought to spaces frequented both by women and by men, the knowledge needed to identify them can pass across different realms, resulting in a similar ability of women and men to identify WEPs.

Similarly, gender does not appear to play a significant role in WEP consumption, as we found similar levels of WEP consumption between women and men in two of the cases (Sierra Morena Extremeña and Sierra Norte de Madrid), with consumption of WEPs being slightly higher among men only in Doñana. There, in semi-structured interviews, men mentioned the consumption of some species, such as Chamaerops humilis, Terfezia arenaria or Juncus acutus, that could be eaten raw in the fields.

"Of course, I know the camarina (Corema álbum). When they are ripe, they turn white. 1 used to eat them in the field." (Man, 75 years old, Almonte.)

"I have eaten a lot of batatillas (Terfezia arenaria). And when I have taken people with me, in my work teams, I have said, 'Look, these are the batatillas.' I have eaten them in front of them, and they have tried them, and many that have tasted them have liked them very much." (Man, 55 years old, Almonte.)

"We have eaten junco fino (Juncus acutus) when we were in the field with the livestock." (Man, 60 years old, Rociana.)

Men in Doñana spend more time in the field than women, especially in the marshes and pine and sandy spaces where they collect some species. Only as a possible hypothesis for future research, we suggest that needs for reward or self-affirmation of masculinity are satisfied through WEP gathering in the wildest areas of Donana, as it occurs regarding the symbolic dimension of the "Saca de las Yeguas", the annual festival around the gathering of the mares staying in marsh areas [47,48]

Thus, the most significant differences refer to WEP gathering, with men reporting gathering more WEP than women in the three case studies, and particularly in Doñana and Sierra Morena Extremeña. There is a double-direction relationship between spaces and activities regarding gender differences. There are gendered activities and, perhaps as a consequence, they put a gender mark on the spaces where they take place. In turn, these areas, as negatively marked for gender, become less accessible for other activities initially not gendered, as we can see when people gather WEPs in agrarian land and silvopastoral areas, as in the case studies analyzed here.

Crossing survey information, secondary data from property structure, bibliography, and our knowledge of the areas, we hypothesize that as a consequence of latifundismo in the southern areas (i.e., Doñana and Sierra Morena), agrarian lands are more masculine spaces than in the Sierra Norte de Madrid (Figure 1 and Table 2). The next sentences are only an example of that.

"Men gather more plants as they are the ones who go to the field. Women have always only gone to the small properties in the ruedo [i.e., the agricultural area surrounding the town] to gather plants. I have always heard things like, 'I told my father, my husband, my friend ... whoever, to bring me chamomile, or whatever other plant.'" (Woman, 57 years old, Almonte.)

Contrarily, in Sierra Norte de Madrid there are less gendered differences in the use of agricultural lands. In this area, among families with lands devoted to agriculture, both women and men conducted agricultural work in households' lands, a situation that equalizes opportunities to gather WEP [28] According to several women from this area, traditionally women were in charge of weeding agricultural fields, where most WEP are gathered in this region: 
"Women did not plow the land, neither cut the grass with the scythe. But they reaped the wheat and threshed the cereal harvest. In the home gardens, women did everything but plowing. They weeded, watered, and harvested even more than men did." (Woman, 80 years old, Valdemanco.)

In sum, we suggest, in the same vein that Porto and Vicente Mazariegos state, latifundismo seems to have weakened the relation between domestic and agrarian spaces [38,42], leading to the masculinization of the distant spaces.

Another factor that might help explain gender differences in WEP gathering is the fact that in southern areas (i.e., Doñana and Sierra Morena), homes are placed in the urban nucleus, distant from gathering areas. Indeed, this settlement pattern was shaped after the Christian conquest and established during the disentitlement process of the nineteenth century [49], although its consequences last to today.

The convergence of both factors (i.e., gendered uses of agricultural lands and physical distance between settlements and agricultural lands) provides a plausible explanation for gender differences in the relation with the territory. As mentioned above, in the South, there are socio-historical reasons that impeded the existence of a large volume of small landowners. This land tenure system hindered a strong relation between households and the countryside, obstructing women's presence in the countryside, where WEPs are more easily found. Both factors (i.e., latifundismo and the distance between settlement and agricultural lands) seem to interact in explaining a gendered differentiation in WEP gathering.

Furthermore, in the southern study areas, the gathering of WEPs and other wild resources has historically been a source of complementary income for some sectors of the population. In areas where latifundismo and rainfed crops dominated, there were long periods of unemployment where dayworkers gathered plants for their own consumption and for sale $[25,26,50,51]$. The distribution of household tasks is better understood by visualizing the activities of a dayworker family during an unemployment period: men gathered Asparagus acutifolius, Scolymus hispanicus or Chamaerops humilis in the countryside, while women would stay in the village with home chores that are continuous all year long. Failing to meet the provider's role, as could happen in the cases of temporary agrarian unemployment, could threaten a man's reputation [52]

As other studies have shown [24], WEP provisioning services have largely decreased in Spain nowadays. WEP are now mostly used for cultural services, related mainly to recreational activities, identity, or self-fulfillment. This is also the case in the study area, as the following sentence reflects:

"I've known these ones [referring to Scolymus hispanicus L. and Rumex pulcher L.] since I can remember. Sometimes we ate them when we were hungry. Nowadays, we do not eat them so often because, thank God, we are overflowing with everything." (Man, 70 years old, Pallares.)

Although new activities are now performed in rural areas, increasing gender equality is leading to changes in the genderization of many spaces. The existence of gender assignments and a collective mindset linked to traditional gender roles perpetuates a certain demarcation of spaces as "more masculine" or "more feminine", regardless of the activities to be conducted in these spaces. Indeed, in Southern Iberia there is a negative connotation of the countryside as distant and untamed [53], and the gender role stipulates that it should be men who face these realms. Moreover, in this region, gathering is not only a masculine activity, but - in some cases_-it even becomes a feature of a specific model of masculinity. In some cases, it is even a mechanism to reaffirm or recreate masculinity. A good example is the case of asparagus gathering in Doñana and, in particular, in Sierra Morena Extremeña, where only men show off their big asparagus bundles gathered in faraway fields [38]

\subsection{Houses, Properties, Villages, and Towns: The Space Genderization}

Using the typology of exclusive production units and familiar production and cohabitation units [23], we can say that in Doñana and Sierra Morena Extremeña, where houses are far from agricultural lands due to the prevalence of large properties, there are not 
familiar production and cohabitation units. Even in small agrarian properties, such as olive groves or vineyards, there are not houses, and families travel daily to their agricultural plots. Consequently, there is not a continuity between homesteads and agricultural lands.

In contrast, in Sierra Norte de Madrid, although there is not strict continuity between houses and agricultural lands (private or communal), there is a more continuous emotional, legal, and pragmatic bond with land. According to Porto and Vicente-Mazariegos's classification, villages in Sierra Norte de Madrid fit into the category of familiar production and cohabitation units, where women are involved in managing the agricultural environment. Thus, although farmers do not live on their fields, the space disposition enables a relation with the natural environment and facilitates family management of agricultural fields. The current masculinization of home gardens might be a consequence of the reduction of the agrarian activities: men have fewer tasks in distant lands, so they now work in home gardens, occupying a realm that was shared with women some decades ago [46]. Despite this trend, the masculinization of agriculture is not as evident as in Sierra Morena Extremeña. Indeed, the spatial distribution in Sierra Norte de Madrid facilitates women moving freely in the fields, and masculinization has been lower than in the southern regions.

It is important to notice that the gendered relation with the territory is constructed since childhood. For example, in southern areas, interviewees told us that girls rarely left the outskirts of the town to play, while boys did venture into the fields, in games that only they practiced, such as hunting birds, fishing frogs, playing cowboys, or making huts. It was unthinkable for a girl or young woman to go alone into the countryside. The following quotations of two women from Pallares (50 and 61 years old) clearly reflect this distinction:

"To the countryside alone? Never. We went, our friends [girls], especially to La Veleta, there behind the corrals, and there, to El Llorón [all less than $500 \mathrm{~m}$ from the village]. To the mountains and that, no, we never went. [...] I like asparagus, but I'm not going to gather them. I just can't see them."

"It never crossed my mind to go to the countryside alone. I don't know if it was out of fear. When I went, it was with my friends [other girls], and here, by the village..."

In contrast, the brothers of these two women went alone to the countryside as young as the age of ten, even to mountains that were several kilometers away from the village.

The same behavior is common among adults, as fields were not considered a suitable place for women to be alone. It was even rare to see a group of women in the mountains. These ideas are embedded in popular culture. Thus, referring to a woman, a popular Andalusian song says: "Don't go alone to the field, as the wind stalks for your apron" (Moscatel, sung by Gracia Montes).

Women's and men's different ways of interacting with the environment in general, and with WEP in particular, can be seen in two additional ethnographic examples, both from Sierra Morena. First, during our survey, we talked to a woman who had lived in the field, in an orchard managed by her family several kilometers away from the village. Although we had been conducting ethnobotanical research in the area for three decades, she was the first person to mention a plant named ahijones. During the two following years, we asked many informants about this plant, but most were not familiar with the name, or did not know where to find it. After two years, it was another woman who finally showed to us the plant (Scandix australis L.). This woman had also grown up in a family that had managed a small orchard several kilometers away from the village. Our second example refers to a workshop on wild plants conducted in Pallares in 2018. The teacher asked the participants to bring specimens of certain specific plants for the workshop, but only a woman went to the field and brought the plants to the workshop. She was also a member of a smallholder family, whose land was far from the village. The three women in these examples grew up in households belonging to the typology of cohabitation and family work units, characterized by a higher involvement of women in agriculture and natural resource management, which is reflected in their WEP knowledge. 
In contrast, our ethnographic information shows that in Sierra Norte de Madrid, both girls and boys used to help in agricultural tasks (i.e., weeding, gathering fresh leaves for the pigs, shepherding). We have observed that in this region, the participation of women and girls was common in the humblest villages, while it was less frequent in villages with better agricultural lands and pastures. Informants explain that there was so much work to do that women and girls had to participate in agricultural tasks, in addition to taking care of the household [46]

"In the fields, men and women worked the same, because it was necessary. Women reaped the cereals, cultivated home gardens, sewed, and harvested. They were shepherds as well." (Man, 81 years old, Montejo.)

Gender differences in WEP collection between Doñana (26.68\%) and Sierra Morena Extremeña $(15.58 \%)$ need further explanations. It is possible that the difference relates to the urban structure predominant in these areas. As in other places in Southern Europe, Doñana is characterized by the presence of agro-towns, or large urban centers concentrating a population primarily working in agriculture, especially dayworkers [54] Agrotowns place the countryside away from the daily, urban, and feminine scope, propitiating a higher presence of men in the agricultural landscape. This urbanistic phenomenon not only sets physical distance between the countryside and the houses, but it also increases the number of social, professional, or recreational interactions that women can establish within the urban centers. Consequently, for people living in agro-towns, activities in the town's vicinity or in the countryside are less frequent and relevant, which helps explain why women's WEP gathering is more common in Sierra Morena Extremeña and Sierra Norte de Madrid than in Doñana.

Although both Doñana and Sierra Morena Extremeña show a structure of latifundist ownership, in Doñana the forest and the marshland are perceived as distinctly male spaces more than in Sierra Morena Extremeña, as we can see in this quotation:

"Most of this kind of plants are in the pinewoods and the marshlands. Men are the ones who usually go there. Not many women have ever been to the marshland. Perhaps there were some cowgirls who would go, but from what I know, this was very unusual. And now, there are even less." (Woman, 57 years old, Almonte.)

\section{Conclusions}

Previous ethnobotanical research has addressed the gender differential; however, our manuscript adds a comparative approach based on empirical data. Beyond identifying differences in how men and women relate to wild edible plants, we examined the causes behind these interactions that lead to the genderization of gathering and the spaces in which it takes place. The main contribution of our work is the identification of structural factors (property and settlement) as key historical elements.

We had some limitations related to the survey design that was not designed to address gender differences. Future research should investigate people' perception of this differential and how they explain genderization. It would be also necessary to do an ethnography of the knowledge, collection, and consumption of plants from a gender perspective. We are already in an early stage of working on a project regarding these issues in Extremadura (Spain).

In this study, we found gender differences in WEP consumption and, especially, gathering. In Southern Spain, gathering takes place largely outside the urban and domestic sphere, in extensive agriculture areas (dehesas, marshlands, pinewoods) that, for cultural and socioeconomic reasons, are especially perceived as masculine spaces. The historical absence of small and medium size agrarian properties in Southern Spain decreases women's possibilities to participate in agricultural tasks, including WEP gathering, at least in comparison to Sierra Norte de Madrid, where a different land tenure predominates. In this central region of Spain, women could establish a productive, affective, and spatial link with agricultural lands. Moreover, agricultural activities were often traditionally shared, mainly in the most isolated villages where the participation of all family members 
was required to assure subsistence. Another factor explaining gendered differences in the study areas is the type of settlement. While in the cases of the Sierra Morena and Sierra de Madrid we find relatively small villages, the predominance of agro-towns in Doñana make the countryside even more distant for those who do not work there every day, including women.

Our study reveals that human-and-nature interactions in the three study areas are gendered. We argue that diverse factors such as spatial patterns and the historical configuration of cultural universes, roles, and gender stereotypes are important criteria that need to be considered in our quest to explain gendered differences in human-plants interactions.

Author Contributions: R.A.-N., M.P.-d.-S., and V.R.-G. designed the research; L.A.-M., P.D., and I.D.R. conducted the research; R.R.-F. and A.J.G.-T. conducted the analysis. R.A.-N. and J.G.-M. wrote the paper with extensive feedback from all coauthors. J.G.-N. helped with the translation. All authors have read and agreed to the published version of the manuscript.

Funding: Research was funded by the Programa de Ciencias Sociales y Humanidades del Ministerio de Economía y Competitividad (España) (CSO2011-27565), with supporting funding from Diputación de Badajoz and Ayuntamiento de Puebla del Maestre.

Institutional Review Board Statement: Ethical review and approval was not required for the study on human participants in accordance with the local legislation and institutional requirements

Informed Consent Statement: Informed consent was obtained from all subjects involved in the study. Written informed consent for participation was not required for this study in accordance with the national legislation and the institutional requirements.

Data Availability Statement: The original data can be accessed contacting the corresponding author/s.

Conflicts of Interest: The authors declare no conflict of interest.

\section{References}

1. Camou-guerrero, A.; Reyes-garcía, V.; Martínez-ramos, M.; Casas, A. Knowledge and Use Value of Plant Species in a Rarámuri Community: A Gender Perspective for Conservation. Hum. Ecol. 2008, 36, 259-272. [CrossRef]

2. Howard, P.L. Women and the plant world: An exploration. In Women and Plants. Gender Relations in Biodiversity Management $\mathcal{E}$ Conservation; Zed Press and Palgrave-Macmillan: London, UK, 2003; pp. 1-48.

3. Pfeiffer, J.M.; Butz, B.J. Assessing cultural and ecological variation in ethnobiological research: The importance of gender. Ethnobiology 2005, 25, 240-278. [CrossRef]

4. Alexiades, M.; Sheldon, J. Selected Guidelines for Ethnobotanical Research: A Field Manual; New York Botanical Garden: New York, NY, USA, 1996.

5. Boster, J. Requiem for the Omniscient Informant: There's life in the Old Girl Yet. In Directions in Cognitive Anthropology; Dougherty, J., Ed.; University of Illinois Press: Champaign, IL, USA, 1985; pp. 177-197.

6. Howard, P.L. Gender bias in ethnobotany: Propositions and evidence of a distorted science and promises of a brighter future. In Proceedings of the International Society of Ethnobiology 9th International Congress and Society for Economic Botany 45th Annual Meeting, Wageningen University \& Research, Wageningen, The Netherlands, 13 June 2004.

7. Díaz-reviriego, I.; González-segura, L.; Fernández-llamazares, Á.; Howard, P.L.; Molina, J.L. Social organization influences the exchange and species richness of medicinal plants in Amazonian homegardens. Ecol. Soc. 2016, 21. [CrossRef] [PubMed]

8. Shaughnessy, S.O.; Krogman, N.T. Gender as contradiction: From dichotomies to diversity in natural resource extraction. J. Rural Stud. 2011, 27, 134-143. [CrossRef]

9. Coldwell, I. Masculinities in the Rural and the Agricultural: A Literature Review. Sociol. Ruralis 2010, 50. [CrossRef]

10. Momsen, J.H. Gender and agrobiodiversity: Introduction to the Special Issue. Singap. J. Trop. Geogr. 2007, 28, 1-6. [CrossRef]

11. García-Reyes, V.; Vila, S.; Aceituno-Mata, L.; Garnatje, T.; Jesch, A.; Lastra, J.; Parada, M.; Rigat, M.; Vallés, J.; Pardo-de-Santayana, M. Gendered Homegardens: A Study in Three Mountain Areas of the Iberian Peninsula 1. Econ. Bot. 2010, 64, 235-247. [CrossRef]

12. Müller, J.; Boubacar, R.; Guimbo, I.D. The "How" and "Why" of Including Gender and Age in Ethnobotanical Research and Community-Based Resource Management. Ambio 2014. [CrossRef]

13. Lowassa, A.; Tadie, D.; Fischer, A. On the role of women in bushmeat hunting e Insights from Tanzania and Ethiopia. J. Rural Stud. 2012, 28, 622-630. [CrossRef]

14. Banerjee, D.; Bell, M.M. Ecogender: Locating Gender in Environmental Social Science. Soc. Nat. Resour. 2006, 20, 3-19. [CrossRef]

15. Carr, E.R. Men's Crops and Women's Crops: The Importance of Gender to the Understanding of Agricultural and Development Outcomes in Ghana's Central Region. World Dev. 2008, 36, 900-915. [CrossRef] 
16. Sunderland, T.; Achdiawan, R.; Angelsen, A.; Babigumira, R.; Ickowitz, A.; Paumgarten, F.; Reyes-garci, V.; Shively, G. Challenging Perceptions about Men, Women, and Forest Product Use: A Global Comparative Study q. World Dev. $2014,1-11$. [CrossRef]

17. Bliege-Bird, R.; Bird, D.W. Why Women Hunt Risk and Contemporary Foraging in a Western Desert Aboriginal Community. Curr. Anthropol. 2013, 49, 655-693. [CrossRef]

18. Kujawska, M.; Luczaj, L. Wild Edible Plants Used by the Polish Community in Misiones, Argentina. Hum. Ecol. 2015, 43, 855-869. [CrossRef]

19. Luczaj, L.; Pieroni, A.; Ardío, J.; Pardo-de-santayana, M.; Sõukand, R.; Kalle, R. Acta Societatis Botanicorum Poloniae and the search for new cuisines involving wild edibles. Acta Soc. Bot. Pol. 2012, 81, 259-270.

20. Schunko, C.; Vogl, C.R. Organic farmers use of wild food plants and fungi in a hilly area in Styria (Austria). J. Ethnobiol. Med. 2010, 6, 1-14. [CrossRef]

21. Stryamets, N.; Elbakidze, M.; Angelstam, P. Role of non-wood forest products for local livelihoods in countries with transition and market economies: Case studies in Ukraine and Sweden. Scand. J. For. Res. 2011, 27, 74-87. [CrossRef]

22. Méndiez, L. Cousas de Mulleres: Campesinas, Poder y Vida Cotidiana (Lugo, 1940-1980); Anthropos Editorial: Barcelona, Spain, 1988.

23. Porto, F.; Mazariegos, V. La implicación de la mujer en la agricultura familiar: Apuntes sobre el proceso de desagrarización de España. Politica Soc. 1991, 9, 15-28.

24. Reyes-García, V.; Menendez-Baceta, G.; Aceituno-Mata, L.; Acosta-Naranjo, R.; Calvet-Mir, L.; Domínguez, P.; Garnatje, T.; Gómez-Baggethun, E.; Molina-Bustamante, M.; Molina, M.; et al. From famine foods to delicatessen: Interpreting trends in the use of wild edible plants through cultural ecosystem services. Ecol. Econ. 2015, 120, 303-311. [CrossRef]

25. Acosta-Naranjo, R. Los Entramados de la Diversidad; Diputación de Badajoz: Badajoz, Spain, 2002; ISBN 8477961034.

26. Acosta-Naranjo, R.; Díaz-Diego, J. Y En Sus Manos la Vida. Los Cultivadores de las Variedades Locales de Tentudía; CEDESCO: Badajoz, Spain, 2008.

27. Acosta-Naranjo, R.; Díaz-Aguilar, A.; Amaya-Corchuelo, S. Memoria de la Tierra, Campos de la Memoria: Los Agroecosistemas Tradicionales de Tentudia; CEDECO: Tentudia, Spain, 2001.

28. Aceituno-Mata, L.; Tardío, J.; Pardo-de-santayana, M. The persistence of flavor: Past and present use of wild food plants in Sierra Norte de Madrid, Spain. Front. Sustain. Food Syst. 2020, 4, 271.

29. Salinas-Fernández, V.; Cacho-Fernández, S. Paisajes y Patrimonio Cultural en Andalucía. Tiempo, Usos e Imágenes; Junta de Andalucía, Consejería de Cultura: Sevilla, Spain, 2010.

30. Ojeda-Rivera, F. Organización del Territorio en Doñana y su Entorno Próximo (Almonte): Siglos XVII-XX; Universidad de Madrid: Madrid, Spain, 1987.

31. Prados, M.; del Valle, C. Naturbanización y cambios en la población de los espacios naturales de Doñana y Sierra Nevada. Doc. Anàl. Geogr. 2010, 56, 435-460.

32. INE Padrón. Población por Municipios. Available online: https://www.ine.es/jaxi/Tabla.htm?path=/t20/e245/p06/10/\&file= 1950.px\&L=0 (accessed on 15 January 2021).

33. INE Padron Población por Municipios. Available online: https://www.ine.es/jaxiT3/Tabla.htm?t=2852 (accessed on 15 January 2021).

34. OCA. Caracterización Agraria del Territorio de la Oficina Comarcal Agraria "Entorno de Donñana"; Junta de Andalucía, Consejería de Agricultura y Pesca y Desarrollo Rural: Huelva, Spain, 2014.

35. Talego, F. Los grupos domésticos jornaleros: Producción de hijos y preparación de la fuerza de trabajo. Rev. Estud. Reg. 1995, 41, 205-228.

36. Rodríguez-Franco, R.; Márquez, V.; Soriano, I. Conocimiento Local en el Olivar Sevillano; APAS: Sevilla, Spain, 2015.

37. Acosta-Naranjo, R.; Rodríguez-Franco, R.; Molina-Fernández, M.; Guzmán-Troncoso, A.J. Los Espárragos en la Construcción de la Masculinidad y la Vinculación al Territorio y la Localidad en la Sierra Morena Extremeña; VI Congreso Internacional de Etnobotánic: Córdoba, España, 2014.

38. Acosta-Naranjo, R.; Guzmán-Troncoso, A.J.; Gómez-Melara, J. The persistence of wild edible plants in agroforestry systems: The case of wild asparagus in southern Extremadura (Spain). Agrofor. Syst. 2020, 94, 2391-2400. [CrossRef]

39. Díaz, M.; Pulido, F.; Marañón, T. Diversidad biológica y sostenibilidad ecológica y económica de los sistemas adehesados. Ecosistemas 2003, 12. [CrossRef]

40. Guzmán-Álvarez, J.R. The image of a tamed landscape: Dehesa through History in Spain. Cult. Hist. Digit. J. 2016, 5. [CrossRef]

41. Ojeda-Rivera, F. Silva-Perez Aproximación a los paisajes de la Sierra Morena Andaluza. In Paisaje y Ordenación del Territorio; Zoido, F., Ed.; Conse- jería de Obras Públicas y Transportes de la Junta de Andalu- cía y Fundación Duques de Soria: Sevilla, Spain, 2002; pp. 71-90.

42. Acosta-Naranjo, R. Dehesas de la Sobremodernidad: La Cadencia y el Vértigo; Diputación de Badajoz: Badajoz, Spain, 2008; ISBN 9788477961697.

43. Sáez-Pombo, E. Montes Públicos, Territorio y Evolución del Paisaje en la Sierra Norte de Madrid; Servicio de Publicaciones de la Universidad Autónoma de Madrid: Madrid, Spain, 2000.

44. Naredo, J.M. La Evolución de la Agricultura en España (1940-2000); Universidad de Granada: Granada, Spain, 2004.

45. Ibancos, C.; Rodríguez-Franco, R. Biodiversidad y Conocimiento local. Las Variedades Cultivadas Autóctonas en el Entorno de Doñana; Junta de Andalucía, Consejería de Agricultura y Pesca: Sevilla, Spain, 2010. 
46. Aceituno-Mata, L. Estudio Etnobotánico y Agroecológico de la Sierra Norte de Madrid. Doctoral Thesis, Universidad Autónoma de Madrid, Madrid, Spain, 2010.

47. Murphy, M.; Gonzalez-Faraco, C. La Saca de las Yeguas en las Marismas de Doñana. In Narria Rev. Artes y Costumbres Pop.; 1999; Volume 81-84, pp. 33-44.

48. Hernández-Ramirez, J. Patrimonio etnológico, identidad y turismo. El caso de "la saca de las yeguas de Doñana. Nuevas Perspect. del Tur. para la próxima década 2012, 799-816.

49. Díaz-Quidiello, J. Atlas de la Historia del Territorio de Andalucía. Junta de Andalucía; Junta de Andalucia: Sevilla, Spain, 2009.

50. Benítez, G.; Molero-mesa, J.; González-, M.R. Gathering an edible wild plant: Food or medicine? A case study on wild edibles and functional foods in Granada, Spain. Acta Soc. Bot. Pol. 2017, 86, 1-27. [CrossRef]

51. Cobo-López, M.; Tijeras-Jiménez, R. Etnobotánica de Doñana; Mancomunidad de Desarrollo y Fomento del Aljarafe: Sevilla, Spain, 2011.

52. Mozo, C.; Tena, F. Antropología de los Géneros en Andalucía. De Viajeros, Antropología y Sexualidad; Mergablum: Sevilla, Spain, 2003.

53. Rodríguez-Becerra, S. Agrociudades en Andalucía. In Proceedings of the IX Jornadas de Etnología de Andalucía, Sevilla, Spain, January 1999.

54. López-Casero, F. La Agrociudad Mediterránea; Ministerio de Agricultura: Madrid, Spain, 1989. 